\title{
Methodology of structured development and validation of multiphysical constitutive models using the example of crushed salt compaction under 3D THM load conditions
}

\author{
Uwe Düsterloh and Svetlana Lerche \\ Lehrstuhl für Deponietechnik und Geomechanik, TU Clausthal, Clausthal-Zellerfeld, 38678, Germany
}

Correspondence: Svetlana Lerche (svetlana.lerche@tu-clausthal.de)

Published: 10 November 2021

\begin{abstract}
The conceptual plans for the final underground disposal of radioactive waste in rock salt formations are based on extensive backfilling with crushed salt of the residual cavities left after waste deposition. It is therefore of particular importance for the historical and prognostic analysis of the load-bearing behavior and impermeability of a final repository in rock salt to demonstrate that compaction of the crushed salt backfill, which progresses over time, is suitable to seal the breaches in the geological barrier created during the underground excavation of the cavity in the long term such that safe containment of the waste is ensured. Relevant investigations on the thermal-hydraulic-mechanical (THM) behavior of crushed salt revealed that the constitutive models for the description of crushed salt compaction, which have regularly been based on the evaluation of oedometer tests, are not suitable for a sufficiently realistic representation of the essentially three-dimensional stress-strain behavior of crushed salt depending on the external load in space and time. Evidence for the above statement lies in particular in the fact that even when standardized mixtures of crushed salt are used, a computational reanalysis of compaction tests using a standardized set of parameters has hitherto been unsuccessful when different loading scenarios were specified for these laboratory tests. This means that deformations and porosities measured in the context of one individual laboratory tests can currently only be reanalyzed in sufficient quantity, irrespective of the choice of constitutive model, if the model parameters are determined in relation to this test. As a result, it must be stated that, on the one hand, the compaction behavior of crushed salt in space and time is not yet definitively understood, while, on the other hand, to ensure reliable, robust and sufficiently realistic statements to be made on compaction behavior, and thus to prove the safe containment of radioactive waste in rock salt, the availability of extensive systematically and sufficiently validated constitutive models is indispensable.

This presentation introduces a methodological approach for the systematic and structured development and validation of multiphysical constitutive models, an approach that has meanwhile been successfully tested many times. The practical application of this methodology will be presented here using the example of a constitutive model that takes into account the triaxial stress-strain behavior of crushed salt. The individual development and validation steps are documented for the crushed salt model, EXPO-COM, newly developed at the Chair for Waste Disposal Technologies and Geomechanics. Validation of the constitutive model is performed by means of a back-analysis of triaxial long-term crushed salt compaction tests as follows:
\end{abstract}

- Test TK-031 of the German Federal Institute for Geosciences and Natural Resources (Bundesanstalt für Geowissenschaften und Rohstoffe, BGR) for isotropic load conditions

- Tests V1 (dry), V2 $(w=0.1 \%)$, and V3 (wet) of the German Society for Plant and Reactor Safety (Gesellschaft für Anlagen- und Reaktorsicherheit $g \mathrm{GmbH}$, GRS) for different stresses and temperature levels as well as humidity

- Test TUC_V2 of the Clausthal University of Technology (TUC) for isotropic and deviatoric stress conditions. 
The TUC_V2 test characterizes, in the context of the methodology for the structured development and validation of multiphysical constitutive models, an innovative test method geared towards constitutive model development, in which the loading boundary conditions specified in the test guarantee the isolated analysis of individual factors influencing compaction behavior (Fig. 1). A description of the tests and test techniques that are still required for the full development and validation of the EXPO-COM constitutive model planned as part of the KOMPASS II research project is given together with a description of methodological guidelines relating to requirements on reliability, functionality, practicability, and validity ranges of the EXPO-COM constitutive model (Fig. 2). As a result of the subsequently possible comparison of experimentally validated and not yet validated dependencies or process variables, a validation status is defined for the constitutive model EXPO-COM. This validation status shows which factors influencing the THM-coupled material behavior of crushed salt are currently sufficiently realistically taken into account, and which influencing factors cannot yet be validated by the constitutive model.

The main objectives of the tests to be carried out as part of the KOMPASS II research project include:

- Continued validation based on the systematized database to be created in KOMPASS II.

- Testing of the constitutive model in the context of numerical analyses of the predictive quality and numerical stability of the constitutive model for in situ relevant stress boundary conditions, prediction times and material properties.

Kurzfassung. Die konzeptionellen Planungen zur untertägigen Endlagerung radioaktiver Abfälle in Salzgesteinsformationen basieren auf einer weitgehenden Verfüllung der nach Abfalleinlagerung verbleibenden Resthohlräume mit Salzgrus. Von besonderer Bedeutung für die historische und prognostische Analyse des Tragverhaltens und der Dichtigkeit eines Endlagers im Salzgestein ist es daher, nachzuweisen, dass die zeitlich fortschreitende Kompaktion des Salzgrusversatzes geeignet ist, die bei der untertägigen Hohlraumauffahrung erzeugten Durchörterungen der geologischen Barriere langfristig derartig zu versiegeln, dass ein sicherer Einschluss der Abfälle gewährleistet wird. Die diesbezüglichen Untersuchungen zum thermisch-mechanischhydraulisch gekoppelten (THM)-Verhalten von Salzgrus ergaben, dass die bisher regelmäßig auf der Auswertung von Ödometerversuchen basierenden Stoffmodelle zur Beschreibung der Salzgruskompaktion nicht geeignet sind, das im Grundsatz dreidimensionale Spannungs-Verzerrungs-Verhalten von Salzgrus abhängig von den äußeren Beanspruchungen in Raum und Zeit hinreichend realitätsnah abzubilden. Ein Beleg für vorstehende Aussage ist insbesondere die Tatsache, dass auch bei Verwendung einheitlicher Salzgrusmischungen eine rechnerische Reanalyse von Kompaktionsversuchen mit einem einheitlichen Parametersatz bisher nicht gelungen ist, wenn im Rahmen der Laborversuche unterschiedliche Belastungsszenarien vorgegeben wurden. Das bedeutet, die im Laborversuch messtechnisch ermittelten Verformungen und Porositäten können unabhängig von der Wahl des Stoffmodells derzeit rechnerisch nur dann hinreichend quantitativ nachvollzogen werden, wenn die Stoffmodellparameter versuchsbezogen festgelegt werden. In der Konsequenz bleibt festzustellen, dass einerseits das Kompaktionsverhalten von Salzgrus in Raum und Zeit noch nicht abschließend bekannt ist, andererseits aber zur Gewährleistung zuverlässiger, robuster und hinreichend realitätsnaher Aussagen zum Kompaktionsverhalten und damit zum Nachweis des sicheren Einschlusses radioaktiver Abfälle im Salzgestein die Verfügbarkeit von systematisch, umfangreich und nachweislich hinreichend validierten Stoffmodellen unverzichtbar ist.

Im Rahmen des Vortrags werden ein mittlerweile mehrfach erfolgreich erprobter methodischer Ansatz zur systematischen und strukturierten Entwicklung und Validierung multiphysikalischer Stoffmodelle vorgestellt und nachfolgend die konkrete Anwendung dieser Methodik am Beispiel eines das dreiaxiale SpannungsVerzerrungs-Verhalten von Salzgrus berücksichtigenden Stoffmodells vorgestellt. Dokumentiert werden die einzelnen Entwicklungs- und Validierungsschritte für das am Lehrstuhl für Deponietechnik und Geomechanik neu entwickelte Salzgrusstoffmodell EXPO-COM. Die Validierung des Stoffmodells erfolgt durch eine Backanalyse von triaxialen Langzeitversuchen zur Kompaktion von Salzgrus wie folgt:

- Versuch TK-031 von BGR (Bundesanstalt für Geowissenschaften und Rohstoffe) für isotrope Beanspruchungszustände;

- Versuche V1 (dry), V2 ( $w=0.1 \%$ ) und V3 (wet) von GRS (Gesellschaft für Anlagen- und Reaktorsicherheit $\mathrm{gGmbH}$ ) für verschiedene Beanspruchungs- und Temperaturniveaus sowie Feuchtegrade;

- Versuch TUC_V2 von TUC (Technische Universität Clausthal) für isotrope und deviatorische Beanspruchungszustände.

Der mit TUC_V2 bezeichnete Versuch charakterisiert im Kontext der Methodik zur strukturierten Entwicklung und Validierung multiphysikalischer Stoffmodelle eine auf die Stoffmodellentwicklung ausgerichtete innovative 
Versuchstechnik, bei der die im Versuch vorgegebenen Belastungsrandbedingungen eine isolierte Analyse einzelner Einflussfaktoren auf das Kompaktionsverhalten garantiert (Abb. 1). Die Beschreibung der für eine im Rahmen des Forschungsvorhabens KOMPASS II beabsichtigte vollständige Entwicklung und Validierung des Stoffmodells EXPO-COM weiterhin erforderlichen Versuche und Versuchstechniken erfolgt in Verbindung mit einer Beschreibung methodischer Kenngrößen zu Anforderungen an Aussagefähigkeit, Funktionalität, Praktikabilität und Gültigkeitsbereiche des Stoffmodells EXPO-COM (Abb. 2). Im Ergebnis der dann möglichen Gegenüberstellung von versuchstechnisch validierten und versuchstechnisch noch nicht validierten Abhängigkeiten bzw. Prozessgrößen wird ein Validierungsstatus für das Stoffmodell EXPO-COM definiert, der zeigt, welche Einflussfaktoren auf das THM-gekoppelte Materialverhalten von Salzgrus aktuell hinreichend realitätsnah berücksichtigt bzw. welche Einflussfaktoren durch das Stoffmodell (noch) nicht erfasst werden können.

Als wesentliche Ziele für die im Rahmen des Forschungsvorhabens KOMPASS II beabsichtigten Untersuchungen sind zu nennen:

- Fortsetzung der Validierung auf Basis der in KOMPASS II zu erstellenden systematisierten Datenbasis;

- Erprobung des Stoffmodells im Rahmen numerischer Analysen zur Prädiktionsqualität und zur numerischen Stabilität des Stoffmodells bei Vorgabe in situ relevanter Beanspruchungsrandbedingungen, Prognosezeiten und Materialeigenschaften.

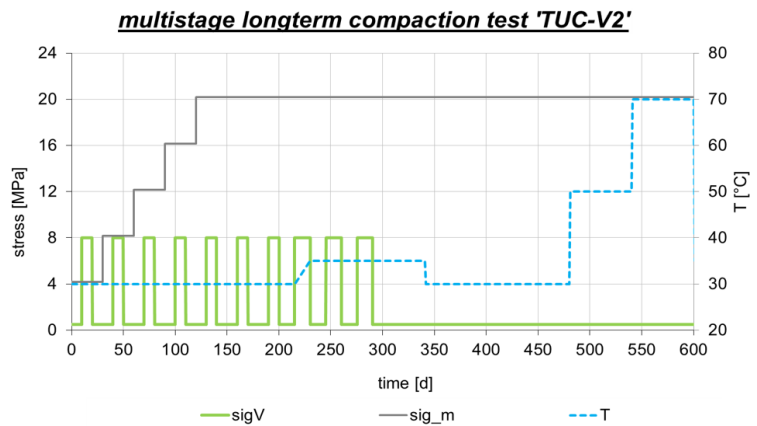

Figure 1. Laboratory experiment TUC_V2.

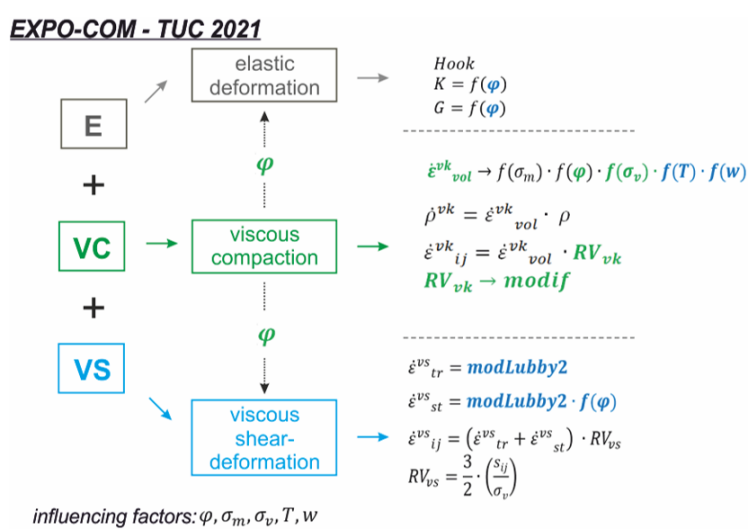

Figure 2. Structure of the EXPO-COM constitutive model of the TUC.

Financial support. This research has been supported by the Bundesministerium für Wirtschaft und Energie (grant nos. 02E11708D and 02E11951D). 